\title{
Pragmatism, Law, and Morality
}

The Lessons of Buck v. Bell

\section{Susan Haack}

\section{(2) OpenEdition}

Electronic version

URL: http://journals.openedition.org/ejpap/821

DOI: 10.4000/ejpap.821

ISSN: 2036-4091

Publisher

Associazione Pragma

\section{Electronic reference}

Susan Haack, « Pragmatism, Law, and Morality », European Journal of Pragmatism and American Philosophy [Online], III-2 | 2011, Online since 29 December 2011, connection on 21 December 2020. URL : http://journals.openedition.org/ejpap/821 ; DOI : https://doi.org/10.4000/ejpap.821

This text was automatically generated on 21 December 2020.

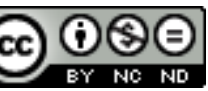

Author retains copyright and grants the European Journal of Pragmatism and American Philosophy right of first publication with the work simultaneously licensed under a Creative Commons AttributionNonCommercial-NoDerivatives 4.0 International License. 


\title{
Pragmatism, Law, and Morality
}

\author{
The Lessons of Buck v. Bell
}

\section{Susan Haack}

\section{AUTHOR'S NOTE}

My thanks to Maribel Narvaez, for comments on an earlier paper of mine that suggested the topic for the present paper; to Mark Migotti, for helpful comments on a draft; and to Pamela Lucken, for skilled help in finding relevant materials.

To say that man is made up of strength and weakness, pettiness and grandeur, is not to draw up an indictment against him: it is to define him.

Denis Diderot ${ }^{1}$

\section{Introduction}

1 Not long ago, ${ }^{2}$ I was startled to read in my morning paper that legislators in North Carolina were nearing consensus on how to compensate roughly 3,000 people who had been involuntarily sterilized under the state's eugenics laws ${ }^{3}$ - the first of which was enacted in $1919,{ }^{4}$ and the most recent of which wasn't repealed until 2003. ${ }^{5}$ Until then, I had no idea such laws had survived so long; now I know that the Mississippi sterilization statute wasn't repealed until $2008^{6}$ - and that a 1909 Washington sterilization statute remains on the books to this day. ${ }^{7}$

Inevitably, my thoughts turned to Justice Holmes's now-notorious ruling for the U.S. Supreme Court in the 1927 case of Buck v. Bell, holding that an order from the superintendent of the Virginia State Colony for Epileptics and the Feeble Minded that inmate Carrie Buck be sterilized didn't violate her constitutional rights; 8 and I began to wonder whether, and if so how, exactly, this ruling should bear on our assessment of Oliver Wendell Holmes's theoretical ideas about the law, and especially of his ideas about the relation of law and morality. 
Traditionally regarded as the first legal pragmatist, Holmes has variously been accused of inconsistency on the subject of law and morality, ${ }^{9}$ of moral skepticism, ${ }^{10}$ and even of "brutalitarianism": ${ }^{11}$ which some might think his ruling in Buck v. Bell confirms. But this, I will argue, is a mistake: Holmes, like James and Dewey, held a kind of moral fallibilism which is far removed from moral skepticism, and conduces neither to inconsistency nor to brutalitarianism; and his ruling in Buck v. Bell, morally misguided as it is, is nevertheless illustrative of Holmes's larger theoretical point, that judges are no less fallible about moral questions than the rest of us, and it's dangerous for them to imagine otherwise.

4 I begin, in \$1, by tracing pragmatist themes in Holmes's legal thinking; and then, in \$2, look more closely at what he has to say specifically about the relation of law and morality. The next step, in \$3, will be to explore the ruling in Buck v. Bell, the history of the case, its context, and its consequences; and finally, in $\$ 4$, I conclude by spelling out some philosophical lessons to be learned from this disturbing, but fascinating, story.

\section{Holmes and his Place in Pragmatism}

"Mr. Justice Holmes," Peirce wrote around 1906, "will not, I believe, take it ill that we are proud to remember his membership" in the Metaphysical Club. ${ }^{12}$ In fact, we know that Holmes was involved even before the first meeting of the club, when James wrote to him in 1868 from Berlin: "When I get home let's establish a philosophical society to have regular meetings and discuss none but the very tallest and broadest questions - to be composed of none but the very topmost of Boston manhood." ${ }^{13}$

6 The son of a well-known physician and poet, ${ }^{14}$ Holmes was certainly among the very topmost of young Boston manhood; and by 1868 he had already taken the first steps on the path that would eventually lead him first to the Massachusetts ${ }^{15}$ and then to the U.S. Supreme Court: ${ }^{16}$ after graduating from Harvard College in 1861 and serving in the Union army for three years during the Civil War ${ }^{17}$ in 1866 he completed his course at Harvard Law School. ${ }^{18}$ But "before turning his mind to the more serious business of the law," Holmes had "sowed his wild metaphysical oats," reading especially the empiricists and the positivists, ${ }^{19}$ and had attended some of Peirce's 1866 lectures on "The Logic of Science."20

7 Still, as the saying goes, the law is a jealous mistress; and after the winter of 1871-72 Homes rarely attended meetings of the Metaphysical Club. ${ }^{21}$ Nor did he ever officially ally himself with pragmatism - not surprisingly, since both his celebrated book, The Common Law (1881), ${ }^{22}$ and his celebrated lecture, "The Path of the Law" (1897) were published before the public debut of the word "pragmatism," in its new, philosophical sense (in James's 1898 lecture, "Philosophical Conceptions and Practical Results"). ${ }^{23}$ Indeed, the evidence seems to be that Holmes didn't clearly distinguish James's pragmatism from his doctrine of the Will to Believe - which, moreover, he dismissed as an "amusing humbug." ${ }^{24}$ And when, many years later, Holmes read Morris Cohen's early anthology of Peirce's work, ${ }^{25}$ what seems to have struck him most forcibly was what he took to be Peirce's curious weakness for wishful thinking "in the direction of religion \&c., [...] despite his devotion to logic." ${ }^{26}$

8 Nevertheless, both legal scholars and historians of philosophy acknowledge Holmes as the first legal pragmatist; ${ }^{27}$ and with good reason, for many themes familiar from the 
philosophers of the classical pragmatist tradition can also be found in Holmes's legal thinking.

9 Here, I can only sketch some of the most important: ${ }^{28}$

10 (i) Law as prediction. Very early on, in 1872, Holmes had written that:

in a civilized state it is not the will of the sovereign that makes lawyers' law, even when that is its source, but what [...] the judges, by whom it is enforced, say is his will [...].".29

11 In 1897, in the first lines of "The Path of the Law," he returns to this theme. The object of legal study, he writes, "is prediction, the prediction of the incidence of the public force through the instrumentality of the courts"; and in the next paragraph he adds:

[...] a legal duty so called is nothing but a prediction that if a man does or omits certain things he will be made to suffer in this or that way by judgment of the court; - and so of a legal right..$^{30}$

Holmes's main point here is that what an attorney advising his client needs to know ${ }^{31}$ isn't the "will of the sovereign," 32 or the provisions as written in the statute books; it is, rather, how those statutes will be interpreted and enforced by the courts. But there is also, as Fisch points out, ${ }^{33}$ a clear affinity with Peirce's statement of the pragmatic maxim:

Consider what effects, that might conceivably have practical bearings, we conceive the object of our conception to have. Then, our conception of these effects is the whole of our conception of the object. ${ }^{34}$

13 And there is, in anything, an even closer affinity with James's version:

The effective meaning of any proposition can always be brought down to some particular consequence in our future practical experience. [...] There can be no difference that doesn't make a difference - no difference in abstract truth that doesn't make a difference in concrete fact. ${ }^{35}$

In short, Holmes shares the (other) pragmatists' concern to get away from mere verbalism, and to clarify meanings by reference to consequences. ${ }^{36}$

(ii) The growth and adaptation of legal concepts. In the opening paragraph of The Common Law, immediately after that memorable line, "the life of the law has not been logic; it has been experience," Holmes writes that judges' interpretation of the law has more to do with "the felt necessities of the time, the relevant moral and political theories, [and] even the prejudices which judges share with their fellow-men" than with the pristinely logical implications of statutory provisions..$^{37}$ Later in the book he suggests why, when he describes how legal concepts shift and change over time: e.g., how older understandings that held animals and even inanimate objects legally responsible for causing injury or death gradually gave way to more modern understandings requiring intent or culpable negligence on the part of a human agent. ${ }^{38}$

Holmes sees such conceptual elasticity as both inevitable and desirable, enabling the law to adapt to new knowledge, to technological developments, and to changing social mores and values. ${ }^{39}$ But this elasticity in legal concepts also means that a legal system can't plausibly be conceived axiomatically, as a system of basic legal-conceptual truths from which correct decisions can simply be deduced - the model proposed by Christopher Columbus Langdell, first Dean of Harvard Law School (whom Holmes once paid the marvelously back-handed compliment, "greatest living legal theologian"!). ${ }^{40}$

Holmes's ideas about the evolution of legal concepts are strikingly reminiscent of Peirce's on the growth of meaning generally - the earliest expression of which comes from the 1866 lectures: 
Science is continually gaining new conceptions. [...] How much more the word electricity means now than it meant in the days of Franklin, [...] how much more the term planet means now than it did in the time [of] Hipparchus. These words have acquired information [...]. In fact, [...] men and words reciprocally educate each other $\left[\ldots . . . .^{41}\right.$

Returning to this theme two decades later, Peirce uses examples not from the sciences, but from the concepts of social life:

Symbols grow. [...] [A] symbol, once in being, spreads among the peoples. In use and in experience, its meaning grows. [...] Such words as force, law, wealth, marriage, bear for us a very different meaning than they bore to our barbarous ancestors. ${ }^{42}$

So Holmes shares not only Peirce's idea that meaning grows, but also Peirce's appreciation of the fact that the enrichment of our vocabulary, far from being an impediment to rationality, can actually enhance the cognitive flexibility and adaptability to changing circumstances that true rationality demands. ${ }^{43}$

(iii) The evolution of legal systems. In his dissenting opinion in Southern Pacific v. Jensen (1917), Holmes writes that:

The common law is not some brooding omnipresence in the sky, but the articulate voice of some sovereign or quasi-sovereign that can be identified [...], the law of some state. ${ }^{44}$

He had long been impatient with the idea of Law-as-such, thinking rather (in the small) in terms of the specific legal system of a place and a time and (in the large) of the whole congeries of legal systems, past, present, and future. And he had long stressed that every legal system is an artifact of history; all have evolved, grown, adapted - and many have died away - in response to changing circumstances. The common law, he writes in "The Path of the Law," has evolved "like a plant," growing, spreading, sporting, adapting to new niches:

The development of [the common] law has gone on for nearly a thousand years, [...] each generation taking the inevitable next step, mind, like matter, simply obeying a law of spontaneous growth. ${ }^{45}$

So we find in Holmes's legal thinking the same evolutionary tendencies that, in various ways, also inform his fellow-pragmatists' thinking about inquiry, language ${ }^{46}$ and even, in Peirce, about the cosmos as a whole. In fact, for a scholar of pragmatism the thought that Holmes expresses here, and even the language he uses, will bring Peirce's agapism - his grand cosmological vision of a universe gradually evolving from chaos to greater order by "affectability"

(vi) Gradualism. "Most differences," Holmes writes in his ruling in Rideout v. Knox (1889), turn out, "when nicely analyzed," to be matters of degree. ${ }^{48}$ of necessity, the law draws sharp lines: e.g., to define the age at which a person is no longer a juvenile but legally an adult, or the level of blood alcohol that constitutes intoxication for legal purposes; but such sharp legal lines are virtually always artificial. It hardly needs saying that this understanding of legal dichotomies as artificial dualisms imposed on what are really differences of degree parallels Dewey's critique of untenable dualisms, ${ }^{49}$ James's hope that pragmatism could bridge the gap between the tough- and the tender-minded ${ }^{50}$ and, of course, Peirce's complaints about those who, flouting the synechistic principle of looking for continuities rather than hard-and-fast distinctions, "do philosophy with an axe" only to end up with "unrelated chunks of being." 51 
(v) The past and the future of the law. We can understand why our legal system is as it is today, Holmes argues, only by looking to its history and to the circumstances in which this or that law or rule arose. "The law embodies the story of a nation's development through many centuries," he writes in The Common Law, and fully to understand it we "must alternately consult history and existing theories of legislation." ${ }^{52}$ In "The Path of the Law" he returns to this theme, writing that the only way we can understand, for example, the doctrine in English law that any physical change to a written contract voids it is to remember that originally a contract was inseparable from the actual physical parchment on which it was written, and couldn't survive the destruction of the parchment or its seal..$^{53}$ But, Holmes continues, we need a better reason for continuing to do things a certain way than that this is what we have always done - especially when the reasons for doing things that way have long since vanished. We should consider, instead:

[...] the ends which [legal] rules seek to accomplish, why those ends are desired,

what is given up to gain them, and whether those ends are worth the price..$^{54}$

In short, Holmes's insistence that to master the law we must look to the future as well as the past conforms to the familiar pragmatist pattern of looking to consequences, the future, the potential..$^{5}$

(vi) The relevance of the sciences, especially the social sciences, to the law. In the same passage of "The Path of the Law" in which he writes of the need to consider ends and means, costs and consequences, Holmes famously observes that "[f]or the rational study of the law the blackletter man may be the man of the present," but "the man of the future is the man of statistics and the master of economics." ${ }^{156}$ But while Holmes speaks here specifically of statistics and economics, it's very clear he has in mind the sciences, especially the social sciences, generally; and the illustration he gives has to do, not with economics, but with criminal psychology:

What better have we than a blind guess to show that the criminal law does more good than harm? [...] Does punishment deter? [...] If the typical criminal is a degenerate, bound to swindle or to murder by as deep-seated an organic necessity as that which makes the rattlesnake bite, [...] he must be got rid of. [...] If, on the other hand, crime, like normal human conduct, is mainly a matter of imitation, punishment may fairly be expected to keep it out of fashion. ${ }^{57}$

One might wish, as I do, that Holmes hadn't written as if all criminals fall either in the "rattlesnake" category or in the "emulating a bad role model" category - his official gradualism notwithstanding, he seems to have succumbed here to not one but two false dichotomies! But for now I will only point out the clear affinities of Holmes's appeal to criminal psychology with the (other) pragmatist philosophers' aspiration to see philosophy work hand in hand with the sciences, ${ }^{58}$ and perhaps especially with Dewey's observations about the relevance of the social sciences, including economics, to ethics. ${ }^{59}$

(vii) Moral fallibilism. This leads me to the last on my list of pragmatist themes to be found in Holmes's writing, and the one that will be most important to the argument that follows: the moral fallibilism that informs his resistance to those "who think it advantageous to get as much ethics into the law as they can." ${ }^{60}$ This is close kin, not only to the fallibilism of James's and Dewey's moral philosophies specifically, ${ }^{61}$ but to the fallibilist spirit of the pragmatist movement more generally. ${ }^{62}$ On this subject, however, Holmes has often been misunderstood; and so, especially in view of its importance to the present argument, it deserves its own section. 


\section{Law, Morality, and Public Sentiment}

"If you want to know the law and nothing else, you must look at it as a bad man"::63 from the perspective, that is, of a person who cares only about the advantages or disadvantages to himself of doing this or that, and is entirely indifferent to what may be morally right or morally wrong. This is Holmes's heuristic device for avoiding the confusions of law and morality that he believed were ubiquitous:

Take the fundamental question, What constitutes the law? You will find some text writers telling you that it is [...] a system of reason, that it is a deduction from principles of ethics or admitted axioms or what not [...]. But if we take the view of our friend the bad man we shall find that he does not care two straws for the axioms or deductions, but he does care what the Massachusetts or English courts are likely to do in fact. I am much of his mind. ${ }^{64}$

His point is that, despite a substantial overlap of their vocabularies ("right," "obligation," "duty," "responsibility," etc.), law and morality are conceptually distinct. Moreover, Holmes continues, even where the law shares a vocabulary with ethics, the words have different meanings in the different contexts; and if we forget this we will inevitably fall into fallacies of equivocation. "[N]othing but confusion of thought," as he puts it, "can result from assuming that the rights of man in a moral sense are equally rights in the sense of the Constitution and the law." ${ }^{65}$

31 Law and morality, Holmes continues, are also different in extension. Some moral rights, obligations, etc., fall outside the scope of the law; and some legal provisions fall outside the scope of morality. As Holmes puts it, "[f]or the most part [the law] falls well within the lines of any [moral] system, and in some cases may extend beyond them." ${ }^{\prime \prime 6}$ At the same time, however, he makes no bones about the fact that "[morally] wrong statutes can be and have been enforced." ${ }^{\prime} 7$

But though he emphasizes the differences (both in intension and in extension) between law and morality, Holmes doesn't deny the moral relevance of law. Far from it. "I take for granted that no reader of mine will mistake what I say for the language of cynicism," he writes; ${ }^{68}$ and roundly declares that the law:

[...] is the witness and external development of our moral life. Its history is the history of the moral development of the race. The practice of it, despite popular jests, tends to make good citizens and good men. ${ }^{69}$

Two points combine here: first, that a legal system reflects the moral sensibilities and moral fault lines of its place and its time, and changes as those sensibilities change; and second, that the rule of law itself brings moral benefits. With respect to the first, evidently at least part of what Holmes has in mind is that judges' interpretations of the law are influenced by their moral attitudes, and that these moral attitudes are usually also those of the community at large - or, often, reflect significant moral disagreements within the community. With respect to the second, it seems he has in mind not only that the rule of law makes life safer and more predictable, but also that a (decent) legal system can enable and encourage moral progress.

Holmes urges that judges look to considerations of "social advantage"; ${ }^{70}$ meaning, as I read him, not that they should advance the interests of this or that social class, but that they should consider the good of society as a whole. True, he also writes of "legal battle grounds where [...] the decision can do no more than embody the preference of a given 
body in a given place and time"; ${ }^{71}$ but the context makes clear this refers only to cases where "the means do not exist for determinations that shall be good for all time." ${ }^{2}$ And in a speech given in 1913 he warns that:

[i]t is a misfortune if a judge reads his conscious or unconscious sympathy with one side or the other prematurely into the law, and forgets that what seem [to him] to be first principles are believed by half his fellow-men to be wrong. ${ }^{73}$

This caution against moral over-confidence echoes Peirce's warnings about "the blight of cocksureness," ${ }^{74}$ the danger of being too sure that you know.

In explaining the difference between legal and moral uses of the same language, Holmes seems to suggest that the law is concerned only with external acts, while morality focuses on intentions. ${ }^{75}$ This can't be right. The law often cares, not only about a person's overt actions, but also about his intent: indeed, mens rea is a key requirement of criminal responsibility. ${ }^{76}$ (No doubt Holmes would greatly have disliked the idea of "hate crime," where the law imposes additional penalties on those convicted of certain crimes if their actions are found to have been motivated by racial or other forms of hatred; ${ }^{77}$ but obviously that doesn't make his diagnosis of the conceptual difference correct.) And sometimes I get the impression that Holmes takes too easily for granted that the "moral development" reflected in the evolution of a legal system invariably moves in the direction of moral improvement. This can't be right either. The history of law e.g., in Nazi Germany, or in South Africa under apartheid, reveals that, sadly, there absolutely is no guarantee of this. ${ }^{78}$

Nevertheless, where Holmes's larger perspective on law, morality, and public sentiment is concerned, I am, as he might say, "much of his mind":79

- Law and morality are conceptually distinct. That's right: to say that it's morally wrong to overburden your secretary with trivial or inappropriate tasks, or to grade your students' papers without actually reading them, is one thing; to say that such behavior is, or should be, legally prohibited is something else entirely.

- Law and morality differ in extension. That's right: many legal norms (e.g., about which side of the road to drive on, or how big a tax break you get if you install a more efficient airconditioner) are morally indifferent; many morally objectionable forms of behavior (e.g., being hurtful or inconsiderate to your spouse, or buying "your" term paper from a commercial outfit that supplies such thingsfor a price) ${ }^{80}$ fall outside the scope of legal regulation; and some legal norms (such as Nazi race laws, "Jim Crow" laws in southern U.S. states, ${ }^{82}$ or the Pakistani law that required four male, Muslim eye-witnesses to prove a charge of rape ${ }^{83}$ are morally deplorable.

- The evolution of a legal system is intimately connected to the moral evolution of the community. That's right: legislators may change existing laws, or impose new ones, and judges may interpret old laws differently (e.g., to forbid the execution of underage criminals ${ }^{84}$ or extend the right to marry to same-sex couples, etc. $)^{85}$ as the moral values of the community shift and change.

- The rule of law itself contributes to the moral life of a community. That's right. The rule of law - in various degrees, depending on the character of the legal system in question - makes life safer and provides a degree of predictability that enables more people to flourish. And a good legal system may actually enlarge the moral vision of a community.

- What is morally right or good isn't something a that judge (or anyone else) can know a priori; and a judge's moral convictions and intuitions (like everyone else's) are fallible. That's right: what moral rules and social arrangements will best enable the most people 
to flourish and get on with the projects that matter to them isn't transparent; it's something that has to be, gradually and often painfully, worked out.

In short: in my estimation, Holmes has a pretty good (though not, to be sure, a perfect) understanding of the relation of law and morality. But whether and, if so, how this assessment can be squared with his ruling in Buck v. Bell is a question that can only be answered by looking more closely at the case and its context - the subject of the next section.

\section{Buck v. Bell and its Background}

The idea of eugenics is very old. In the 6th century B.C., Theognis had complained that, while we are careful to breed the best cattle and horses, among humans "everything is mixed, noble and base," leading to a "degraded, motley" race of men. ${ }^{86}$ More famously, in Book V of Plato's Republic, drawing an analogy with breeding hunting dogs, Socrates proposes that in the ideal city "the best men must have sex with the best women as frequently as possible, while the opposite is true of the most inferior men and women." ${ }^{17}$ But the word "eugenics" wasn't coined until 1883, when Francis Galton introduced it to refer to "all influences that tend to however remote a degree to give the more suitable races or strains of blood a better chance of prevailing speedily over the less suitable." 88

41 Galton was second cousin to Charles Darwin, who had observed in The Origin of Species (1859) that, while the usual mechanism of evolution was natural selection, human beings have contributed to the process artificially by selectively breeding strains of animal and plant potentially useful to them:

We cannot suppose that all the breeds [of domesticated animals and plants] were suddenly produced [...] as we now see them; indeed, in several instances we know this has not been their history. The key is man's power of accumulative selection. ${ }^{89}$

Nature provides the variations; human beings select those they find desirable, and so, by artificial selection over many generations, create new breeds of domestic animal or plant. 90

In The Descent of Man (1871), Darwin extends his theory to the origin of human beings. Discussing the effect of civilization on natural selection, he writes that "[among savages] the weak in body or mind are soon eliminated," but that in civilized societies we "do our utmost to check the process of elimination," so that the weak survive to propagate their kind; and continues, "[n]o one who has attended to the breeding of domestic animals will doubt that this must be highly injurious to the race of man." In this context, he cites Galton. ${ }^{91}$

Gregor Mendel's work on the genetics of inheritance, published in 1865, had gone largely unnoticed for decades. But by 1900 other scientists had rediscovered Mendel's laws; ${ }^{92}$ and in the early years of the twentieth century many took for granted that laws like those Mendel had found to govern the inheritance of the height of pea plants or the color of their flowers could easily be extrapolated to complex human traits like feeblemindedness or criminal tendencies. The stage was set for the rise of the eugenics movement.

In Hereditary Genius (1870), Galton had written that "the wisest policy" is to "retard the average age of marriage among the weak, and [...] hasten it among the vigorous classes." ${ }^{93}$ In 1905 , he proposed new statistical studies of inherited family traits. ${ }^{94}$ In his memoirs, 
published in 1909, he advocated measures to prevent people seriously afflicted by "lunacy, feeble-mindedness, habitual criminality, and pauperism" from reproducing their kind..$^{95}$ The aim of eugenics, he averred, is "to check the birth-rate of the Unfit," and to "further[] the productivity of the Fit," thus "bringing no more individuals into the world than can be properly cared for, and those of the best stock." ${ }^{96}$ And in a fragment of a work of fiction, "The Eugenic College of Kantsaywhere," published posthumously, Galton described a world - by his lights, a utopia - where citizens are examined for physical, mental, aesthetic and "ancestral" fitness. A grade of "Pass" in Genetic Fitness allows the candidate to marry and reproduce. A grade of "Honours" privileges him or her to make a "College marriage" with another such graduate. Those who fail, however, are forbidden to procreate; and for "the idiots, insane and the Feeble-minded," genetically the least fit, reproduction is a crime, to be severely punished. ${ }^{97}$

That was fiction; but it didn't take long for such ideas to take firm hold in the real world. ${ }^{98}$ In Britain, where there was much concern about the "degeneration" of the race, Sir William Beveridge (who would play a key role in the establishment of the welfare system) thought that, while "unemployables" should be taken care of, they should also be deprived of all rights of citizenship, including the right to "fatherhood"; and Winston Churchill told a delegation from the National Association for the Care of the FeebleMinded that such people should be segregated "so that their curse die[s] with them." ${ }^{99} \mathrm{~A}$ eugenicist thread runs through the anti-individualist, "scientific" socialism of Sidney and Beatrice Webb, ${ }^{100}$ and can be seen in Karl Pearson's declaration that "the child is economically a commodity." ${ }^{101}$

And in the U.S. too, enthusiasm for eugenics was on the rise. ${ }^{102}$ The first U.S. eugenics law was passed in Indiana in $1907^{103}$ and by 1924 , the year of the Virginia law challenged in Buck, similar laws had been passed in Washington, California, and Connecticut (1909), Nevada, Iowa, and New Jersey (1911), New York (1912), North Dakota, Kansas, Michigan, and Wisconsin (1913), Oregon, South Dakota, and New Hampshire (1917), North Carolina and Alabama (1919), and Montana and Delaware (1923). ${ }^{104}$ Kansas had the dubious distinction of enacting the most severe of these laws, going so far as to make it a crime "for any managing officer of a state institution to fail to recommend the sterilization of any inmate 'unfit to procreate"'; ${ }^{105}$ California - where the law applied to inmates of all state institutions and anyone convicted three times of any offence and deemed to be a "sexual or moral pervert," and after 1919 to the insane as well as the feeble-minded - had the dubious distinction of performing the largest number of compulsory sterilizations. ${ }^{106}$

Some eugenic sterilization bills, however, were defeated in state legislatures, ${ }^{107}$ and others were vetoed by the governor of the state concerned. ${ }^{108}$ And some eugenics statutes had already been challenged in the courts. In 1917, for example, a federal judge ruled that performing a vasectomy on repeat-offender Rudolph Davis under the Iowa statute "for the Unsexing of Criminals, Idiots, etc." ${ }^{109}$ constituted cruel and unusual punishment, and so was unconstitutional. ${ }^{110}$ Shortly thereafter, Iowa repealed the law Davis had challenged. ${ }^{111}$ The year after that, a federal court had reversed the sentence, under a Nevada law, that convicted rapist Pearley Mickle be sterilized. ${ }^{112}$

By this time, the Eugenics Record Office (ERO), founded in 1910 at the initiative of biologist Charles Davenport and run by biology teacher Harry Laughlin, had spearheaded a program of research, publication, and training of field workers in eugenics. ${ }^{113}$ At the first national conference on Race Betterment [sic], held in Michigan in 1914, Laughlin presented details of the program of sterilization to eliminate the eugenically unfit that he 
had already spelled out in an ERO publication; along with a "Model Sterilization Law" intended "to prevent the procreation of feebleminded, epileptic, inebriate, criminalistic and other degenerate persons by authorizing and providing by due process of law for the sterilization of persons with inferior hereditary properties." 114

In 1921, the Chief Judge of the Chicago Municipal Court, Henry Olson, met Laughlin at a Eugenics Congress in New York, and the next year re-edited and subsidized the reissue of Laughlin's book, Eugenical Sterilization. ${ }^{115}$ The new edition included a final part, written by Olson, arguing that the Model Law was constitutionally valid. Limiting reproduction for the good of society, he argued, was no less constitutional than executing criminals, conscripting citizens into military service, or requiring compulsory vaccinations. ${ }^{116}$ The legally key points, he thought, were that compulsory sterilization be presented, not as punishment for a crime, but as for the good of the "patient"; and that adequate procedural safeguards be included.

51 The same year, 1922, G. K. Chesterton argued in Eugenics and Other Evils that the "stuffy science, [...] bullying bureaucracy, [...] [and] terrorism by tenth-rate professors" characteristic of eugenics posed a serious threat to individual liberty. ${ }^{117}$ Two years later, J. B. S. Haldane observed that "some of the most ferocious enemies of human freedom" were advocating for eugenics laws; ${ }^{118}$ Walter Fernauld, president of the American Association for the Study of the Feeble-Minded, criticized the simple hereditarian view of mental defect; 119 and even eugenicist Samuel J. Holmes acknowledged that "[ $t]$ here is a great deal of rubbish written" on the subject, and that "many of the most important problems are still very puzzling." ${ }^{\prime 20}$ But by this time the eugenics bandwagon was unstoppable.

52 The same year, 1924, the state of Virginia passed a law providing that "the health of the patient and welfare of the community may be promoted in certain cases by the sterilization of mental defectives," and that a vasectomy or salpingectomy ${ }^{121}$ may be performed on "any patient [sic] afflicted with hereditary forms of insanity, imbecility, etc." ${ }^{122}$ The Virginia law followed Laughlin's model in being premised on the idea that compulsory sterilization would be not only for the good of society generally, but also for the good of the person sterilized - because after the operation he or she could safely be released from the Colony and support him- or herself in the outside world; and in including provisions for notice and a hearing.

Under the provisions of this law, the superintendent of the State Colony for Epileptics and the Feeble Minded had ordered that Carrie Buck - "a feeble-minded white woman who was committed to the [...] Colony [,] [...] the daughter of a feeble-minded woman in the same institution, and the mother of an illegitimate feeble-minded child" ${ }^{123}$ - be sterilized. When it became apparent that this would be an important test case, the ERO sent Arthur H. Estabrook to Virginia to testify for the state, and Laughlin himself supplied a deposition. ${ }^{124}$ First the Circuit Court of Amherst County, Virginia, and then the Supreme Court of Appeals of the State of Virginia, affirmed the order, ${ }^{125}$ and in 1927 the case came to the U.S. Supreme Court.

54 Carrie Buck's attorney argued that the superintendant's order was unconstitutional under the Fourteenth Amendment; specifically, that "it violates her constitutional right of bodily integrity and is therefore repugnant to the due process of law clause of the Fourteenth Amendment." ${ }^{126}$ By a majority of $8-1,{ }^{127}$ however, the Court ruled that Carrie Buck's con- stitutional rights had not been violated, and that Virginia could go ahead and 
sterilize her as planned. ${ }^{128}$ At the request of then-Chief Justice (and former President) William Howard Taft, ${ }^{129}$ Holmes wrote the ruling for the majority.

Most unusually, the ruling in Buck is only three pages long, and includes only one citation to an earlier case - a case, moreover, not about compulsory sterilization, but about compulsory vaccinations. Most of the ruling is taken up with arguments, first, that the Virginia statute included many safeguards to ensure that "the rights of the patient are most carefully considered," and second that, in this instance, "every step was taken in scrupulous compliance to the statute." ${ }^{130}$ What the plaintiff really claims, Holmes continues, is not that the statute didn't provide for proper procedure, and not that, though proper procedures were provided for, they weren't followed in this instance, but that such a law is inherently unconstitutional - that in no circumstances could such an order be justified. But, Holmes continues, "[w]e have seen more than once that the public welfare may call upon the best citizens for their lives," and "[i]t would be strange if it could not call upon those who already sap the strength of the state for these lesser sacrifices [...]." ${ }^{131}$ The Virginia statute falls under the same principle that allows laws requiring compulsory vaccinations, which the Court had earlier found constitutional. ${ }^{132}$ Holmes then briskly dismisses the argument that, since it applies only to inmates of the State Colony, the law violates equal protection: "the law does all that is needed when it does what it can. ${ }^{{ }^{133}}$ And, in the most notorious line of this most notorious ruling, he declares: "[t]hree generations of imbeciles are enough." ${ }^{134}$

Perhaps you will notice - what struck me the first time I heard this, and still strikes me again every time I think about it - that while it is undeniably rhetorically powerful, in a grim kind of way, it is also maddeningly illogical. The way to avoid a fourth generation of imbeciles, surely, would have been to sterilize not only Carrie Buck, but also her infant daughter, Vivian. And perhaps, when you read Holmes's argument that the state sometimes calls on citizens to make much greater sacrifices than this, you will wonder, as I do, whether he was remembering the thousands of young men who died in the terrible civil war in which he had himself fought long before. But none of this really bears on Holmes's and his colleagues' legal reasoning.

Probably you will also notice, as I do, that Holmes simply takes the alleged key facts of the case, that all three generation of Buck women (Carrie, her mother, Emma, and her daughter, Vivian) were "feeble-minded," for granted. ${ }^{135}$ Many years later, Stephen Jay Gould would conclude that all three were mis-diagnosed. ${ }^{136}$ But it's not the Supreme Court's job to determine questions of fact, but to decide questions of law; so this doesn't really help either.

Apparently, though, to Holmes and the seven colleagues who voted with him, the case seemed, legally, an easy one. Only a couple of years before Buck, after all, the Supreme Court of Michigan had found an order that a feeble-minded young man be sterilized constitutional - arguing that biological science has definitely demonstrated that feeblemindedness is hereditary; that the right to beget children may be outweighed by concerns about the common welfare; and that compulsory sterilization is analogous to compulsory vaccination. ${ }^{137}$ Holmes and his colleagues, like the majority of the Justices of the Michigan Supreme Court, took it to be a known scientific fact that feeble-mindedness was hereditary, and that eugenics laws were in the interests of society. Statutes that imposed sterilization as punishment for certain crimes had already been ruled unconstitutional under the prohibition on cruel and unusual punishment, and eugenics statutes that didn't provide adequate procedural safeguards, in the form of appropriate 
notice and a hearing, had already been ruled unconstitutional under the requirement of due process of law; but the Virginia statute was carefully crafted to avoid these constitutional pitfalls. And at this time the standard of review employed by the Supreme Court in equal-protection cases was simply that there be a "rational basis" for the lower court's allowing a statute that applies only to a sub-class of citizens, ${ }^{138}$ a requirement the Virginia statute - which applied to inmates of the Colony, who were wards of the state also satisfied.

To have grasped the potential dangers, and found plausible constitutional grounds for invalidating the statute, would have required not only much more careful scrutiny of scientific opinion (where, as we have seen, there was already dissent from some), but also a serious exercise of epistemic, moral, and legal imagination - though not, I have to add, a superhuman exercise of the imagination. (In Michigan, after all, the three Justices who dissented in Smith had recognized the disturbing weakness of the science and the alarming potential for abuse of compulsory-sterilization laws). ${ }^{139}$

Reactions to the Buck ruling in the press and in medical and other journals are quite revealing. The ruling gives states "the right to protect society" (the New York Times); it "would result to [Carrie Buck's] advantage," by allowing her to be released from the Colony (the Richmond (VA) Times-Dispatch); Holmes's "classic" ruling is in accord "with the most progressive tendencies in our social machine" (the Charlottesville (VA) Daily Progress); the decision provides "the remedy for imbecility" (the Gastonia (NC) Daily Gazette); it "protect[s] the world against morons" (the Davenport (IA) Democrat and Leader); it teaches us that we don't "dispose of enough human weeds" (the Helena (MT) Daily Independent); it should "convince open-minded folk that such legislation is wise" (the Montgomery ( $A L$ ) Advertizer); it "opens future possibilities of vast importance in the field of eugenics and public health" (the Journal of the American Medical Association); it would "halt the imbecile's perilous line" (the Literary Digest). ${ }^{40}$

61 Some reaction was more critical: the Daily Herald, for example, cautioned that eugenic sterilization was "not a panacea," and the Philadelphia Evening Bulletin worried that such programs might go to extremes. But, though "sentimentalists were vexed," Time magazine reported, "eugenicists cheered" the ruling. ${ }^{141}$ Eugenicists cheered, all right one might say they gloated. Among them was Western State Asylum Superintendent Joseph DeJarnette, a long-time advocate of eugenic sterilization ${ }^{142}$ and an expert witness at the first Buck trial. ${ }^{143}$ The Virginia law, Dejarnette wrote in the Virginia Medical Monthly for January 1931, would "prevent a great deal of unhappiness, murders, crimes, drunkenness and accidents," and make the state "safer, saner, and better to live in"; and wraps up his argument with some dreadful doggerel on the subject of "Mendel's Law":

Oh, why are you men so foolish -

You breeders who breed our men

Let the fools, the weaklings and crazy

Keep breeding and breeding again? The criminal, deformed, and the misfit,

Dependent, diseased, and the rest -

As we breed the human family The worst

is as good as the best ${ }^{144}$

... and so on and on, for four more verses.

Not surprisingly, after the Supreme Court's ruling in Buck other states also passed eugenics laws: Idaho, Utah, Minnesota, and Maine in 1925; Mississippi in 1928; West Virginia in 1929; Arizona in 1929; Vermont and Oklahoma in 1931; South Carolina in 1935; and 
Georgia in $1937 .{ }^{145}$ Not surprisingly, either, legal challenges to such laws continued: for example, in 1933 the Supreme Court of North Carolina ruled that, because the state's 1931 sterilization statute made no provision for notice and a hearing, it violated the "due process" clause of the Fourteenth Amendment to the Constitution; ${ }^{146}$ in 1935 the Supreme Court of Alabama advised the Governor that a sterilization bill passed by the state legislature was unconstitutional for the same reason; ${ }^{147}$ and in 1942 a 1921 Washington law was also found to violate due process. ${ }^{148}$

The same year, 1942, the U.S. Supreme Court returned to the subject of eugenics laws for the first time since Buck. Skinner v. Oklahoma was a test of the constitutionality of the Habitual Criminal Sterilization Act passed by the Oklahoma legislature in 1935, which provided that a person convicted twice or more of crimes "amounting to felonies involving moral turpitude" (in Oklahoma or any other state), and then convicted of a third such crime in Oklahoma, "shall be rendered sexually sterile." ${ }^{149}$ Jack Skinner had been convicted in 1926 of stealing chickens, and in 1929 and again in 1934 of robbery with firearms. When the Act passed, he was an inmate in the Oklahoma state penitentiary; and the state Attorney General instituted proceedings to have him vasectomized. ${ }^{150}$

Skinner argued that this violated his fourteenth amendment rights; and this time the Supreme Court agreed. By 1942, the standard of review of lower courts' decisions on equal-protection claims was significantly more stringent than it had been in 1927, now requiring "strict scrutiny." 151 This case, the Court argued, was distinguishable from Buck: the Oklahoma law clearly violates the "equal protection" clause, since it mandates sterilizing someone convicted three times of larceny but not someone convicted three times of embezzlement - even though the nature of these crimes is the same, and they are (in other respects) punishable in the same manner. ${ }^{152}$

Moreover, Justice Douglas continues:

We are dealing here with legislation which involves one of the basic rights of man. Marriage and procreation are fundamental to the very existence and survival of the race. The power to sterilize, if exercised, may have subtle, far reaching and devastating effects. In evil or reckless hands it can cause races or types which are inimical to the dominant group to wither and disappear. ${ }^{153}$

What is most striking about this passage - besides the way it begins by announcing the existence of a "basic human right," and then proceeds to interpret the Constitution so as plant the seed of a corresponding legal right - is that it suggests that public sentiment on the subject of eugenics had begun to shift, perhaps because the racial horrors of the Nazi regime had been known in the U.S. since $1935 .{ }^{154}$ These dicta aside, however, Skinner still falls into the old legal pattern, invalidating the Oklahoma law on familiar constitutional grounds.

In $1953 \mathrm{~J}$. E. Coogan argued that it was time for the Supreme Court to overturn Buck; ${ }^{155}$ but this has never happened. In 1960, noting how easily they could be abused, the American Medical Association questioned the wisdom of eugenics laws; ${ }^{156}$ but in 1962 a study by the Virginia Advisory Legislative Council found "no medical or other scientific data" to show that the 1924 statute needed revision. ${ }^{157}$ And for many years after Skinner courts ruled other states' compulsory-sterilization statutes constitutional. In 1968, for example, the Supreme Court of Nebraska - arguing that while the right to procreate is "a natural and constitutional right," nonetheless "no citizen has any rights that are superior to the common welfare" - ruled in Cavitt that the state's compulsory-sterilization law was constitutionally valid. ${ }^{158}$ 

significantly. In 1965, an article in the journal of the American Bar Association observed that "today's authorities doubt" the supposed scientific basis for sterilization laws; ${ }^{159}$ and Justice Smith's dissenting opinion in Cavitt cited a then-recent statement by the South Dakota Medical Association (itself citing numerous articles and textbooks) to the effect that, with rare exceptions, it was by no means established that heredity is a factor in the development of mental disease. ${ }^{160}$ The following year, a law review article pointed out that, because the number of people actually affected by a genetic defect is always small relative to the number of carriers, sterilizing only those in whom the gene is expressed would do little to wipe out the defect. ${ }^{161}$ Nor, I should add, are the children of a mentally impaired parent always or inevitably similarly impaired. decisions in which the Supreme Court's Fourteenth Amendment jurisprudence evolved specifically in application to questions of marriage and reproduction. In Loving (1967) the Court struck down a Virginia statute making interracial marriage a crime, arguing that this violated "the central meaning of the Equal Protection clause." 162 In Eisenstadt v. Baird (1972) the Court struck down a Massachusetts statute that permitted married but not single people to obtain contraceptives, recognizing "the right of an individual to be free of unwarranted government intrusion into matters [...] [such] as the decision whether to bear or beget a child." ${ }^{163}$ And in Roe v. Wade, the Supreme Court's landmark 1973 ruling on abortion, the Court held that "the right of personal privacy" allowed abortions in the first trimester of pregnancy, though it added that this right "is not unqualified, and must be considered against important state interests in legislation," so that "regulation limiting certain fundamental rights" may be justified by 'a compelling state interest'." 164 including Virginia, which in 1975 finally repealed the statute challenged in Buck. A couple of years later, in New York - where in 1919 a 1912 law authorizing sterilization of persons in institutions had been held unconstitutional under the equal protection clause - the Surrogates Court of Nassau County denied an application by the parents of D.D. (a severely retarded but physically well-developed 16-year-old) to have their daughter sterilized, arguing that to allow it would violate her fundamental right to bear children. ${ }^{166}$ Other states, however, continued to uphold compulsory-sterilization statutes - notably, in 1977, North Carolina. ${ }^{167}$ Since Buck, the state Supreme Court argues in Moore, many states had passed sterilization laws; and most had been found constitutional if "notice and a hearing are provided, if [the law] applied equally to all persons, and if [sterilization] is not prescribed as a punishment for a crime." ${ }^{168}$ The "fundamental right" articulated in Roe v. Wade was not unlimited, the ruling continues, and "the interest of the unborn child is sufficient to warrant sterilization in certain instances." ${ }^{169}$

This legal saga is so fascinating that it's tempting to keep going, and continue the story to the present day. But that would take a book; and anyway, it's high time I returned to the questions about Holmes's legal philosophy with which I began.

\section{Lessons to be Learned}

In the legal history briefly recounted here there is some confirmation of Holmes's observations to the effect that what the law is depends on what judges (at least, I would 
add, what judges at the highest court) say it is. As Justice Driver wrote for the Supreme Court of Washington in 1942, "[s]ince the United States Supreme Court, in 1927, decided the case of Buck v. Bell, "it is considered settled that so far as its substantive features are concerned, a sterilization statute such as we have here is within the police power of a state." ${ }^{170}$ Moreover, the story I have told provides confirmation of Holmes's observations about the evolution of legal concepts - in this instance, of the concepts of equal protection and the right to privacy.

74 Of course, the story also reveals that what Holmes regarded (with good reason) as a deleterious confusion of legal and moral senses of the word "right" can also be a very effec- tive rhetorical tool for bringing about legal change. ${ }^{171}$ As we saw in Skinner, the argument that a legal provision violates a fundamental moral right can motivate the first steps towards the creation of a corresponding legal right.

In the early decades of the twentieth century, Nils Roll-Hansen reminds us, eugenics was "a science-based movement to combat threatening degeneration, [...] initiated by idealistic scientists [...] and inspired by a humanistic Enlightenment ideal." ${ }^{172}$ Legal rulings, as we saw, reflected this. So Holmes's ruling in Buck arguably conforms to his advice, in "The Path of the Law," that when considering what interpretation of the law would be for the good of society, judges look to the sciences.

Of course, the story recounted here also reveals the danger that the science to which judges look may be weak, over-simplified, out-of-date or, even if it is sound, poorly understood by policy makers and lawyers ${ }^{173}$ - a danger of which Clarence Darrow had warned in 1926, while Buck was on appeal. ${ }^{174}$ This is not to suggest that Holmes's advice that judges look to the sciences was inherently flawed - it was good advice, up to a point; but it is to say that judges should exercise considerable caution not to take the reliability of plausible-sounding but poorly established and perhaps seriously flawed scientific work too readily for granted.

The rise of eugenics laws in the U.S. and elsewhere clearly reflected prevailing moral and social attitudes, and the way such laws subsequently fell into disrepute clearly reflected significant changes in moral and social sensibilities; confirming Holmes's idea that the evolution of a legal system reflects the moral evolution of the community. And most importantly for present purposes, this story also provides confirmation of Holmes's moral fallibilism, his sense that what truly contributes to the greater good of society isn't something of which judges (or anyone) can be certain.

In the early decades of the last century many legislators and judges, Holmes included, were evidently convinced that eugenics laws would prevent crime and degeneracy, physical, mental, and moral, and so serve "considerations of social advantage" - that they were, like laws requiring vaccinations or the isolation of patients suffering from certain communicable diseases, small sacrifices demanded of individuals for the greater good of society. But already in 1926 Darrow had expressed alarm at "the sureness of the advocates of this new [eugencist] dream [...] their ruthlessness in meddling with life [...] their stern righteousness," 175 and warned of "the pain and suffering that men have inflicted upon each other by their cocksureness and their meddling." ${ }^{176}$ And to us, now knowing what do about how catastrophic Nazi race laws, especially, proved to be, and accustomed to thinking of a person's right to privacy and reproductive freedom as unassailable - the Supreme Court's ruling in Buck seems both politically naive and 
morally blind; but to them, then, it seemed an entirely reasonable sacrifice to ask of individuals for the welfare of society, a moral step forward.

Don't get me wrong. I'm not saying that Holmes's ruling in Buck was a morally good one given what he thought he knew about the heritability of feeble-mindedness; only that even though, by my lights, this ruling manifested a real failure of moral imagination and judgment - this failure was understandable given what Holmes and his colleagues thought they knew. Reading Buck, I find myself wishing that Holmes and his colleagues had even half of Darrow's, or Chesterton's, ability to see the potential for abuse in such laws. But I have learned from Holmes to reflect that others - for example, Chinese friends accustomed to many years of the "one-child" policy, ${ }^{177}$ and with a long cultural history of stress on social cohesion over individual rights ${ }^{178}$ - might disagree; and to acknowledge that it's hard not to feel some sympathy for the parents of children like D.D. ${ }^{179}$

Hence my conclusion: For all his Olympian detachment, ${ }^{180}$ Holmes was only human made up, like the rest of us, "of insight and blindness, pettiness and grandeur." He was absolutely right to stress that it is a "misfortune" when a judge "reads his conscious or unconscious sympathy with one side or the other" - or his own moral convictions prematurely into the law. The fact that Holmes failed to practice, in Buck, what he preached in "The Path of the Law," shouldn't blind us to the importance of this pragmatist theoretical insight.

\section{NOTES}

1. Addition aux pensées philosophiques (c.1792); my source is The Oxford Book of Aphorisms, ed. John Gross, Oxford, Oxford University Press, 1983, 24-5.

2. () 2011 Susan Haack. All rights reserved.

3. Valerie Bauerlein, "State Mulls Amends for Sterilizations," Wall Street Journal, June 10, 2011, A3.

4. Chapter 281, Public Laws of North Carolina, Session 1919. This law "was undoubtedly intended to provide for sterilization operations though the word [...] did not occur." A subsequent statute enacted in 1929 was declared unconstitutional by the state Supreme Court in 1933, and was replaced by a new law the same year. See Elsie L. Porter, Biennial Report of the Eugenics Board of North Carolina, July 1, 1946 to June 30, 1948 [archive.org/details/biennialreporteug07nort].

5. There is a table of when states enacted and repealed such laws in Paul A. Lombardo, Three Generations, No Imbeciles: Eugenics: The Supreme Court, and Buck v. Bell (Baltimore, Johns Hopkins University Press, 2008), p. 294.

6. $\S \S 41-45-1$ to $41-45-19$ of the Mississippi code were repealed by Laws 2008 , ch.412, §50, eff. July 1, 2008. (At this time Lombardo's book (note 000 above) would have been in press, so he lists this Mississippi law as still "intact").

7. 1909 c. 249 § 35; RRS §2287 (1909) remains in force. (In 1921, however, Washington introduced a new sterilization statute, L. '21, § 6957-6969, which was overturned in 1942).

8. Buck v. Bell, 274 U.S. 200 (1927). [Dr. John Bell was a physician at the Colony.]

9. See e.g., Lon Fuller, The Law in Quest of Itself (1940; Boston, Beacon Press, 1966), p. 118; Morton

G. White, Social Thought in America: The Revolt Against Formalism (1947; New York, Viking Press, 
1949), p. 69-70; Henry M. Hart, “Holmes's Positivism - An Addendum," Harvard Law Review, 64, 1951: 929-37, p. 932.

10. See e.g., Albert W. Altschuler, Law without Values: The Life, Work, and Legacy of Justice. Holmes (Chicago, University of Chicago Press, 2000).

11. Westwood Pegler, "Fair Enough," Boston Evening American, December 18, 1950: 34, 35, 45, p. 34

12. Charles Sanders Peirce, Collected Papers, eds. Charles Hartshorne, Paul Weiss and (vols. 7 and 8) Arthur Burks (Cambridge, MA: Harvard University Press, 1931-58), 5.12 (c.1906). [Referred to in what follows as $C P$.]

13. Quoted in Ralph Barton Perry, The Thought and Character of William James (Boston, Little Brown and Company, 1935), II, p. 91.

14. Oliver Wendell Holmes Sr., "supplemented his income from a meager Boston medical practice by lecturing on anatomy at Harvard Medical School and [...] on literary subjects to general audiences"; and in 1856 "began writing a series of essays and poems collectively entitled 'The Autocrat of the Breakfast Table' for the Atlantic Monthly [...]" that made him a well-known public figure. Sheldon Novick, “A Brief Biography of Justice Holmes," in Novick, ed., Collected Works of Oliver Wendell Holmes (Chicago, University of Chicago Press, 1993), vol. 1, 8-17, p. 8.

15. Holmes was appointed to the Massachusetts Supreme Judicial Court in December 1881, and chiefjustice in 1889. Novick (note 14 above), p. 11.

16. Holmes served on the U.S. Supreme Court from 1902 to 1931. Id., p. 15.

17. During the Civil War Holmes "was wounded three times, twice near fatally, and suffered from dysentery." Id., p. 9.

18. Interestingly, this involved his attending Harvard Law School for only a little over a year. Ibid

19. Id., I, 229-30.

20. Philip P. Weiner, Evolution and the Founders of Pragmatism (Cambridge, Harvard University Press, 1949; reprinted, Philadelphia, PA, University of Pennsylvania Press, 1972), 75. These lectures on "The Logic of Science: Or, Induction and Hypothesis," are published in Writings of Charles S. Peirce: A Chronological Edition (Bloomington, Indiana University Press, 1982-present), 1.358-504.

21. At any rate, Fisch reports, in 1927 Holmes told Charles Hartshorne that he "soon dropped out of the band." Max Fisch, "Was There a Metaphysical Club in Cambridge?," in Studies in the Philosophy of Charles Sanders Peirce, eds. Edward Moore and Richard Robin (Amherst, University of Massachusetts Press, 1964), 5-32, p. 22.

22. Oliver Wendell Holmes, The Common Law (1881); reprinted in Novick, Collected Works (note14 above), vol. 3, 109-324. "The Path of the Law," Harvard Law Review, 10, 1897: 457-78, id., vol. 3, 391-406.

23. William James, "Philosophical Conceptions and Practical Results," University Chronicle (University of California, Berkeley), September 1898; reprinted in James, Pragmatism (1907), eds. Frederick Burkhardt and Fredson Bowers (Cambridge, Harvard University Press, 1975), 257-70. Peirce had articulated the Pragmatic Maxim twenty years before, in "How to Make Our Ideas Clear" (CP 5.388-410 (1878)), but hadn't used the word "pragmatism," for fear of being misunderstood.

24. Holmes, letter to Frederick Pollock, June 17th, 1908), in Mark DeWolfe Howe, ed., HolmesPollock Letters: The Correspondence of Mr. Justice Homes and Sir Frederick Pollock, 1874-1932, MA, Harvard University Press, 1941), 1: 139.

25. Morris R. Cohen, ed., Chance, Love, and Logic (Lincoln, University of Nebraska Press, 1923).

26. "The Holmes-Cohen Correspondence," ed. F. M. Cohen, Journal of the History of Ideas, 9, 1948: 3-57, p. 34. Of course, Holmes's reaction was more than a little ironic: for Peirce himself evidently found James's Will to Believe doctrine quite troubling; and indeed, the year after The Will to Believe 
and Other Essays in Popular Philosophy was published (1879), can be found urging, instead, the "Will to Learn," a genuine desire to discover the truth. Peirce, CP 5.583 (1898).

27. Richard Posner lists among those who "philosophized" pragmatism "Emerson, and later Peirce, Oliver Wendell Holmes, Jr., William James, John Dewey, George Herbert Mead, and others." Law, Pragmatism, and Democracy (Cambridge, Harvard University Press, 2003), p. 12. Legal scholar reference. Max Fisch describes The Common Law as "full of the spirit of pragmatism from the ringing sentences in which its theme is announced - 'the life of the law has not been logic; it has been experience' - to the end." Max H. Fisch, "Justice Holmes, The Prediction Theory of the Law, and Pragmatism" (1942), in Kenneth Lane Ketner \& Christian Kloesel (eds.), Peirce, Semeiotic and Pragmatism (Bloomington, Indiana University Press, 1986), 6-18, p. 8. (Fisch even suggests (id., p. 8) that Peirce's pragmatic maxim may have been a generalization of Holmes's idea of law-asprediction, rather than the other way around.) Wiener's Evolution and the Founders of Pragmatism (note 20 above) includes a chapter on "Evolutionary Pragmatism in Holmes's Theory of the Law." 28. These and other pragmatist themes are also woven into the "neo-classical legal pragmatism" I developed in "The Pluralistic Universe of Law: Towards a Neo-Classical Legal Pragmatism," Ratio Juri 1.4, 2008: 453-80.

29. Holmes, Note, American Law Review 6, 1871: 723-5. Reprinted in Novick (note 14 above), vol.1, 294-7; the quotation is from p. 295.

30. Holmes, "The Path of the Law" (note 22 above), p. 391.

31. This qualification is important, since the idea that a judge is predicting what he will decide seems implausible to say the least.

32. John Austin, Lectures on Jurisprudence, or: The Philosophy of Positive Law (London, John Murray, 1869).

33. Fisch, "Justice Holmes, the Prediction Theory of Law, and Pragmatism" (note 27 above), p 12.

34. Peirce, CP 5.401 (1878). I am also reminded of Peirce's later reflections on laws of nature: "Law, without force to carry it out, would be a court without a sheriff; and all its dicta would be vaporings." Id., 1.212 (1902). Peirce makes the same point again in a letter to Lady Welby, dated 1904 (8.330); and at 7.523 (n.d.).

35. James, "Philosophical Conceptions and Practical Results" (note 23 above), p. 259, 260.

36. For a fuller treatment, see Susan Haack, "On Legal Pragmatism: Where Does 'The Path of the Law' Lead us?," American Journal of Jurisprudence, 50, 2005: 71-105; reprinted in Pragmatism Today [ pragmatismtoday.eu/] (forthcoming 2012).

37. Holmes, The Common Law (note 22 above), p. 115.

38. Id., p. 118.

39. On the evolution of legal concepts of causation in response to new forms of transportation and manufacturing, for example, see L. M. Friedman, A History of American Law (New York, Simon and Schuster, 1973), p. 409 ff. See also Susan Haack, "Risky Business: Statistical Proof of Individual Causation," forthcoming, in Spanish translation, in Jordi Ferrer Beltrán (ed.), Causación $y$ atribución de responsibilidad (Madrid, Marcial Pons). [English version available from the author on request.]

40. Christopher Columbus Langdell, A Selection of Cases on the Law of Contracts (1871; 2nd ed. (Boston, Little, Brown, 1879). Oliver Wendell Holmes, "Book Notice" (of William Anson, Principles of the English Law of Contracts and Langdell, Selection of Cases on the Law of Contracts, 2nd ed.), American Law Review, 14, 1880: 233-5, p. 234. For a much fuller treatment of Langdell's model and Holmes's critique, see Susan Haack, “On Logic in the Law: 'Something, but not All," Ratio Juris, 20.1 2007: 1-31.

41. Peirce, CP 7.587 (1866).

42. Id., 2.302 (c.1895).

43. For a much fuller treatment, see Susan Haack "The Growth of Meaning and the Limits of Formalism, in Science and Law," Análisis filosófico, XXIX.1, 2009: 5-29. 
44. Southern Pacific v. Jensen, 244 U.S. 205, 222 (1917) (Holmes, J., dissenting).

45. Holmes, "The Path of the Law" (note 22 above), p. 398.

46. See e.g., Peirce, “The Fixation of Belief," CP 5.358-387 (1877); Dewey, “The Influence of Darwin on Philosophy" (1909) in Dewey, The Influence of Darwin on Philosophy and Other Essays in Contemporary Thought (New York, Peter Smith, 1951), 1-19; George Herbert Mead, Mind, Self, and Society (Chicago, University of Chicago Press, 1934).

47. Peirce, CP 6.104 (1892). See also Susan Haack, "The Legitimacy of Metaphysics: Kant's Legacy to Peirce, and Peirce's to Philosophy Today," Polish Journal of Philosophy, 1, 2007: 29-43; re-printed in Philosophical Topics, 36.1, 2008: 97-110.

48. Rideout v. Knox, 148 Mass. 368, 19 N.E. 390 (1889). Reprinted in Harry C. Shriver (ed.), The Judicial Opinions of Oliver Wendell Holmes: Constitutional Opinions, Selected Excerpts and Epigrams as Given in the Supreme Judicial Court of Massachusetts, 1883-1902 (Buffalo, Dennis \& Co., 1940), 162-6.

49. See e.g., Dewey, "The Inclusive Philosophical Idea," in Philosophy and Civilization (New York, Capricorn Books, 1931), 77-92 (on the untenable dualism of the natural vs. the social); "Body and Mind," id., 299-317 (on the untenable dualism of mind vs. body).

50. James, "The Present Dilemma in Philosophy," in Pragmatism (1907), eds. Frederick Burkhardt and Fredson Bowers (Cambridge, Harvard University Press, 1975), 9-26.

51. Peirce, CP 7.750 (which the editors describe as probably from the 1898 Cambridge series). See also Susan Haack, "Not Cynicism but Synechism: Lessons from Classical Pragmatism," Transactions of the Charles S. Peirce Society, XLI.2, 2005: 239-53; reprinted in John Shook and Joseph Margolis, eds., Companion to Pragmatism (Oxford, Blackwell, 2006), 141-53, and in Haack, Putting Philosophy to Work: Inquiry and Its Place in Culture (Amherst, Prometheus Books, 2008), 79-94.

52. Holmes, The Common Law (note 22 above), p. 115.

53. Holmes, "The Path of the Law" (note 22 above), p. 402.

54. Id., p. 404.

55. See e.g., John Dewey, “The Development of American Pragmatism," Philosophy and Civilization (note 49 above), 13- 35 .

56. Id., p. 399. "Black letter law" is "an informal term indicating the basic principles of law generally accepted by the courts and/or embodied in the statutes of a particular jurisdiction." Black's Law Dictionary (St. Paul, West Publishing Co., 1990), p. 170.

57. Holmes, "The Path of the Law" (note 22 above), p. 400.

58. See e.g. Peirce, CP 5.4112 (1905) (describing pragmatism as expressing “the experimentalist's view of assertion"); 6.1-5 (1898) (urging the need for scientific metaphysics). James, Pragmatism (n.50 above), p. 31 (envisaging philosophy and the sciences as working together).

59. Dewey, "The Construction of Good," chapter 10 of The Quest for Certainty (New York, Capricorn Books, 1929).

60. Holmes, "The Path of the Law" (note 22 above), p. 394.

61. James, "The Moral Philosopher and the Moral Life" (1891), in James, The Will to Believe and Other Essays in Popular Philosophy (1897); eds. Frederick Burkhardt and Fredson Bowers (Cambridge, Harvard University Press, 1979), 141-62. Dewey, "Intelligence and Morals" (1908), in The Influence of Darwin on Philosophy (note 46 above), 46-76; "The Construction of Good" (note 59 above).

62. "Out of a contrite fallibilism," Peirce writes, "combined with a high faith in the reality of knowledge, all my philosophy has always seemed to grow." CP 1.14 (c.1897).

63. Holmes, "The Path of the Law" (note 22 above), p. 392.

64. Id., 393.

65. Ibid.

66. Ibid.

67. Ibid.

68. Id., 392. 
69. Ibid.

70. Id., 398.

71. Id., 397.

72. Ibid.

73. Holmes, "Law and the Court," speech at a dinner of the Harvard Law School Association of New York, February 15, 1913, in Julius J. Marke (ed.), The Holmes Reader (Dobbs Ferry, Oceana Docket Series, 1955; 2nd ed., 1964), 64-6, p. 65.

74. Peirce, CP 1.13 (c.1897).

75. Holmes, "The Path of the Law" (note 22 above), p 395.

76. "Mens rea" is "[a]n element of criminal responsibility; a guilty mind; a guilty or wrongful purpose; a criminal intent.” Black's Law Dictionary (note 56 above), p. 985.

77. In the early 1990s a number of states (among them Wisconsin, California, Florida, Vermont, Montana, and Mississippi) had enacted such penalty-enhancement statutes. Proposed federal legislation to the same effect passed the House of Representatives in 1992, but failed in the Senate. The relevant federal statute was codified in 2009. "Hate Crime Acts," 18 U.S.C. $\$ 249$ (Supp. III 2009). Wisconsin v. Mitchell, 508 U.S. 476 (1993), 482 n.4.

78. A point discussed at greater length in "On Legal Pragmatism" (note 36 above), p. 92-5.

79. For a fuller development of my own view of the relation of law and morality, see the concluding section of Susan Haack, "Nothing Fancy: Some Simple Truths about Truth in the Law" (2011); forthcoming in Spanish translation in Jorge Cerdio, ed., Truth in the Law (Place, Marcial Pons). [English version available from the author on request.]

80. No, I am not making this up! See Ed Dante, "The Shadow Scholar: The Man Who Writes Your Student Papers Tells His Story," Chronicle of Higher Education, November 12, 2010 [chronicle.com/ article/The-Shadow-Scholar/125329].

81. On Nazi law, see Michael Stolleis, The Law Under the Swastika: Studies in Legal History in Nazi Germany (1994; trans. Thomas Dunlap, Chicago, University of Chicago Press, 1998).

82. On "Jim Crow" laws, see Charles S. Mangum, The Legal Status of the Negro (Chapel Hill, University of North Carolina Press, 1940); C. Vann Woodward, The Strange Career of Jim Crow (1955; 2nd, revised ed., New York, Oxford University Press, 1966).

83. "Islam and Rape," Wall Street Journal, August 3, 2006, A6 (the law was repealed the following year).

84. Roper v. Simmons, 543 U.S. 551 (2005).

85. See e.g. National Conference of State Legislatures, "Same-Sex Marriage, Civil Unions and Domestic Partnerships" [ncsl.org/default.aspx?tabid=16430].

86. I rely here on Smith v. Command, 204 Northwestern Reptr., 140, 147 (1925) (Justice Wiest, dissenting).

87. Plato, Republic. Translated by G. M. A. Grube, revised by C. D. C. Reeve (Indianapolis, Hackett Publishing Company, 1992), Book V, 459.

88. Francis Galton, Inquiries into Human Faculty and Its Development (London, MacMillan, 1883), p. 24, n.11. Galton was also the initiator of the point-counting method of fingerprint identification. See Galton, "The Pattern in Thumb and Fingermarks," Proceedings of the Royal Society of London, 48, 1890: 455-7; "Methods of Indexing Finger-Marks," Proceedings of the Royal Society of London, 49, 1890-1: 540-8.

89. Charles Darwin, The Origin of Species by Natural Selection: Or, The Preservation of Favoured Races in the Struggle for Life (1859; ed. J. W. Burrow, Harmondsworth, Middlesex, Penguin Books, 1968), p. 89-90.

90. Id, 90 .

91. Charles Darwin, The Decent of Man and Selection in Relation to Sex (1871; revised ed., Chicago, Rand McNally and Company, 1874), p.130, citing Francis Galton, "Hereditary Character," MacMillan's Magazine, 12, 1865: 157-66, and Hereditary Genius: An Inquiry into its Laws and 
Consequences [(1870); ed. H. J. Eysenk, reprinted from the 1878 edition (London, Julian Friedmann Publishers \& New York, St Martin's Press, 1978)].

92. See Genome News Network, “Genetics and Genomics Timeline [genomenewsnetwork.org/ resources/timeline/1866_Mendel.php].

93. Galton, Hereditary Genius (note 91 above), p. 352 in the 1978 reprinted edition.

94. Francis Galton, "Studies in Eugenics," American Journal of Sociology, 11.1, 1905: 11-25. Despite its title, this paper doesn't actually report any studies in eugenics; rather, after a survey of various marriage customs, it proposes a research program in eugenics. It also envisages a proposed systemof awarding certificates of genetic fitness (p. 23).

95. Francis Galton, Memories of My Life (New York, E. P. Dutton, 1909), p. 311.

96. Id, 323.

97. Francis Galton, “The Eugenical College of Kantsaywhere" (tentatively dated 1911, the year of Galton's death), transcribed and edited by Lyman Tower Sargent, Utopian Studies, 12.2, 2001: 191-205. The quotation is from p. 202.

98. As Galton reports in "Studies in Eugenics" (note 94 above), p. 20-1, the Francis Galton Research Fellowship in National Eugenics at the University of London had been established in 1909. But the eugenics movement was soon world-wide. Alison Bashford \& Philppa Levine (eds.), The History of Eugenics (Oxford, Oxford University Press, 2010) includes papers on eugenics in Britain, Southern Asia, Australia and New Zealand, China and Hong Kong, Kenya, France, the Netherlands, Scandinavia, Southern Europe, Eastern Europe, the Soviet Union, Japan, Iran, Cuba, Puerto Rico and Mexico, Brazil, Canada, the U.S, and, of course, Germany.

99. Stephen Trombley, The Right to Reproduce: A History of Coercive Sterilization (London, Weidenfeld and Nicholson, 1988), p. 22-3.

100. Id., 35-40.

101. Id., 40-4.

102. There is even a hint of such ideas in Peirce, who once wrote that imprisonment was barbaric, and that serious criminals should be"confined in relative luxury, making them useful, and preventing reproduction." CP 2.164 (1902) (italics mine). And James had written that "our kindliness for the humble and the outcast [...] wars with that stern weeding-out which until now has been the condition of every perfection in the breed." The Moral Philosopher and the Moral Life (note 61 above), p. 157.

103. The Indiana law allowed for the compulsory sterilization of "confirmed idiots, imbeciles, and rapists" in state institutions. By 1911, at which point 873 men had been sterilized under this law, the governor threatened to cut the budgets of state mental institutions, ending the practice. Trombley (note 99 above), p. 51.

104. Lombardo (note 99 above), p. 294.

105. Trombley (note 99 above), p. 65-6.

106. Id., 51-3. By January 1, 1944, California had sterilized 17.012 people. Id., p. 53.

107. In 1897, for example, compulsory-sterilization bills had been defeated in Michigan and Kansas. Lombardo (note 5 above) p. 21.

108. In 1905, for example, a sterilization law passed the Pennsylvania legislature, but was vetoed by the governor. Trombley (note 99 above), p. 50-1.

109. Laws of the 35th General Assembly of Iowa, 1913, ch. 202. This law, Trombley points out, was "particularly wide-ranging," covering "criminals, idiots, feeble-minded, imbeciles, drunkards, drug fiends, epileptics, syphilitics, moral and sexual perverts, [...] prostitutes, twice convicted sex offenders and thrice-convicted felons," and could be enforced for "eugenic, punitive, or therapeutic grounds." Trombley (note 99 above), p. 63-4.

110. The Eighth Amendment to the U.S. constitution (ratified in1791) provides that "[e]xcessive bail shall not be required, nor excessive fines imposed, nor cruel and unusual punishments 
inflicted." The Constitution of the United States with the Declaration of Independence and the Articles of Confederation, ed. R. B. Bernstein (New York, Barnes and Noble, 2002), p. 65.

111. Lombardo (note 5 above), pp. 28-9, citing Davis v. Berry, 216 Fed. 413 (S.D. Iowa, 1914), and Davis v. Berry, 242 U.S. 468 (1917). Despite the fact that the law had already been repealed, in 1917 the Supreme Court heard the state's appeal against the federal court's decision; the twoparagraph ruling (written by Holmes, and largely concerned with procedural defects in the state's case), directed that the appeal be dismissed.

112. Mickle v. Henrichs, 262 Fed. 687 (Nev. 1918).

113. Lombardo (note 5 above), p. $30 \mathrm{ff}$.

114. Id., $47 \mathrm{ff}$. The quotation is from p. 51.

115. Laughlin, Eugenical Sterilization in the United States (Chicago, Psychopathic Laboratory of the Municipal Court of Chicago, 1922). According to Stephen Jay Gould, Laughlin's model law served as the basis for the Nazis' Erbgesundsheitsrecht, under which, by 1939, more than 375.000 people were sterilized. Stephen Jay Gould, "Carrie Buck's Daughter" (in his column “This View of Life ), Natural History, 93.7, July 1984: 14-18, p. 14.

116. Lombardo (note 5 above), p. 81-90.

117. I rely here on Trombley (note 99 above), p. 83 (citing Chesterton, Eugenics and Other Evils (1922) but giving no page number).

118. Lombardo (note 5 above), p. 147, citing J. B. S. Haldane, "Eugenics and Social Reform," New Republic, 39, June 25, 1924: 118-9, p. 118.

119. Id., 146.

120. Ibid., citing Samuel J. Holmes, A Bibliography of Eugenics (Berkeley, University of California Press, 1924), p. 2.

121. The word refers to the operation of tying and cutting the Fallopian tubes.

122. Buck (note 8 above), 205-6.

123. Id., 205.

124. Gould (note 115 above), p. 15-6.

125. Buck v. Bell, 130 S.E. (Supreme Court of Appeals of Virginia, 1925).

126. Trombley (note 99 above), p. 89. The Fourteenth Amendment to the Constitution of the United States, ratified in 1868, provides in part that no State shall deprive a citizen of life, liberty, or property "without due process of law," nor deny anyone within its jurisdiction "equal protection of the laws" Bernstein (note 110 above), p. 68.

127. It is worthy of note that Justice Brandeis (known for his defense of the right to privacy) voted with the majority; and that the sole dissenter, Justice Butler (a Roman Catholic father of seven children), left us no written opinion explaining his grounds. Lombardo (note 5 above), p. 173 (Brandeis), 171-2 (Butler). For some reason, Lombardo is severely critical of Holmes's part in this decision, but excuses Brandeis's vote as understandable given the social context.

128. Buck's request for a rehearing was denied. Id., p. 177-81.

129. Id., 165-6.

130. Buck v. Bell (note 8 above), 207.

131. Ibid. This argument, Lombardo points out, was also to be found in earlier eugenicist literature. Lombardo (note 5 above), p. 171.

132. Buck v. Bell (note 8 above), 207, citing Jacobson v. Massachusetts, 197 U.S. 11 (1905).

133. Id., 208.

134. Id., 207.

135. In this context it is worth noting that in 1875 Oliver Wendell Holmes Sr. had published an article, "Crime and Automatism" (Atlantic Monthly, 35, 1875: 466-81), including the story of the nine hundred descendants, over six generations, of a girl called Margaret, at least two hundred of whom, he reports, were known criminals, and a large number of "idiots, imbeciles, drunkards, and [persons] of otherwise degraded character." Id., 475. 
136. Gould, "Carrie Buck's Daughter" (note 115 above). The case of Vivian Buck seems the clearest: as a small baby, she was described as feeble-minded by a social worker who thought she didn't look quite normal; but she attended Venable Public Elementary School in Charlottesville, VA, from 1930-32, where she seems to have been a average student, and was even listed on the honor roll in April 1931. She died in 1932 of an intestinal disorder. Carrie Buck supposedly had the IQ roughly of an nine year old; but according to Prof. Lombardo (who wrote to Gould that he had met her and seen her reading the newspaper and doing the crossword), she was neither mentally ill nor retarded. Id., 16. Carrie was committed, Gould argues, because she was pregnant and unmarried. As for Emma Buck, all Gould says is that "we have no more reason to suspect her than her daughter of true mental deficiency" (p. 17).

137. Smith v. Command (note 86 above), 141 (the biological evidence is overwhelming), 142 (the right to bear children is not absolute, the analogy with compulsory vaccinations).

138. I rely here on Charles W. Murdock, "Sterilization of the Retarded: A Problem or a Solution?," California Law Review, 62, 1974: 917-35, p. 921.

139. Smith v. Command (note 86 above), $146 \mathrm{ff}$. (Justice Wiest, with whom Justices Fellows and Bird concurred, dissenting).

140. I rely here on Lombardo (note 5 above), pp.174-5. (The abbreviations in parentheses indicate the state in which a newspaper was published.)

141. Id.

142. Id., 76.

143. Id., 121-7, 136.

144. J. S. DeJarnette, "Eugenic Sterilization in Virginia," Virginia Medical Monthly, January 1931: 678-680. The quotations are from p. 680. I am irresistibly reminded of Sinclair Lewis's Dr. Pickerbaugh, the fictional public-health officer of the fictional town of Nautilus - though the doggerel he spouts about "A heathy mind in A clean body," and such is much funnier, and much less sinister, than DeJarnette's effort. Sinclair Lewis, Arrowsmith (1927l New York, Signet Classics, 1998), chapters 19-24.

145. Lombardo (note 5 above), p. 294.

146. Brewer v. Valk, 204 N.C. 188, 167 S.E. Rptr. 638 (1933) (distinguishing the 1931 North Carolina statute from the Virginia statute at issue in Buck v. Bell on the grounds that it did not provide for notice and hearing).

147. In Re. Opinion of the Justices, 162 Southern Rptr. 123 (1935) (distinguishing the proposed Alabama law from the Virginia statute at issue in Buck v. Bell on the grounds that its procedural provisions were inadequate).

148. In re. Hendrickson, 123 Pacific Rptr. 2d 323 (1942).

149. Okl.St.Ann. Tit 57, s 171 et seq; L.1935, p. 94 et sq.

150. Skinner v. Oklahoma, 316 U.S. 535, 536 (1942).

151. I rely here on Lewis F. Powell, Jr., "Carolene Products Revisited," Columbia Law Review, 82.6, 1982: 1087-1105 (recognizing United States v. Carolene Products, 304 U.S. 1444, 152 n.4 (1938) as the source of the new, stricter standard).

152. Id., 538-9. Equal protection, the ruling continues, is compatible with distinguishing degrees of evil, but not with treating those convicted of the same degree of evil differently. Id., 540 .

153. Id., 541.

154. Lombardo (note 5 above), p. 227 (noting that Georgia passed its sterilization law in 1937, after the horrors of the Nazi regime were beginning to be known).

155. Id., 241.

156. Id., 243, citing J. E. Coogan, "Eugenic Sterilization Holds Jubilee," Catholic World, 177, April 1953: 45-50; "State Sterilization Law: Great American Fraud," Tucson Register, May 1, 1953.

157. Ibid., citing "Reappraisal of Eugenic Sterilization Laws," Journal of the American Medical Association, 173, July 16, 196: 1245-50. 
158. In re. Cavitt, 157 N.W.2d 171 (Supreme Court of Nebraska, 1968). The quotation is from 175. 159. Regina Bligh, "Sterilization and Mental Retardation," ABA Journal, 51, 1965: 1059-63, p. 1061. 160. In re. Cavitt (note 158 above), 179-80.

161. William R. Matoush, Note, "Eugenic Sterilization: A Scientific Analysis," Denver Law Journal, 46, 1069: 631-56, p.643. See also Rex Dunn, Note, "Eugenic Sterilization Statutes: A Constitutional Re-Evaluation," Journal of Family Law, 14, 1975: 280-308, which summarizes a good deal of the then-recent literature.

162. Loving v. Commonwealth of Virginia, 87 S.Ct. 1817, 1823 (1967).

163. Eisenstadt v. Baird, 405 U.S. 438,452 (1972).

164. Roe v. Wade, 410 U.S. 113, 154-5.

165. The other nine states were Alabama, Arizona, California, Idaho, Indiana, Maine, Michigan, New Hampshire, North Dakota and South Dakota. (I rely on Joel Alan Fischman, Note, "In re. Truesdell: North Carolina Adopts Two New Conflicting Standards for Sterilization of Mentally Retarded Persons," North Carolina Law Review, 64, 1986:1196-1215, n.58.)

166. Matter of D.D., 90 Misc.2d 236 (1977). (It is worth noting that the parents' concern wasn'tthat D.D.'s children would also be retarded, but that, with a mental age of less than five, their daughter was quite incapable of caring for a child.)

167. The statute at issue, which came into effect in January 1975, "sought to correct the defects found in the former statute." In re. Sterilization of Moore, 321 S.E. 307 (1976), 309, 310. On the complicated history of North Carolina sterilization statutes, see Fischman (note 165 above), pp. $1202 \mathrm{ff}$.

168. Id., 309. On the history of such cases, the court cites Validity of Statutes Authorizing Asexualization of Criminals or Mental Defectives, 53 A.L.R.3d 960 (1973).

169. Id., 312. (The question that springs to mind, of course, is: "what unborn child?")

170. In re Hendrickson (note 148 above), 324 (italics mine). (Recall that the ruling held the Washington statute unconstitutional not in substance, but for lack of adequate procedures.)

171. A point illustrated, in very different ways, in two recent books: Mary Ann Glendon, The Forum and the Tower: How Scholars and Politicians have Imagined the World, from Plato to Eleanor Roosevelt (New York, Oxford, 2011), chapter 12 (on the history of the United Nations Declaration of Human Rights); Walter Olsen, Schools of Misrule: Legal Academia and an Overlawyered America (New-York, Encounter Books, 2011).

172. Nils Roll-Hansen, "Eugenics and the Science of Genetics," in Bashford and Levine, The History of Eugenics (note 98 above), 82-97, p. 83.

173. More recent examples of judicial over-reliance on flawed science aren't hard to find; see e.g, Barefoot v. Estelle, 463 U.S. 880 (1983), where the Supreme Court ruled that Thomas Barefoot's constitutional rights weren't violated when he was sentenced to death after the testimony of two psychiatrists that he would be dangerous in future - even though the American Psychiatric Association itself acknowledged that such predictions are wrong two times out of three.

174. [T]alk about breeding for intellect, in the present state of scientific knowledge and data, is nothing short of absurd." Clarence Darrow, "The Eugenics Cult," American Mercury, 8.30, June 1926: 129-37, p. 134.

175. Id., 135.

176. Id., 137.

177. See my interview with Chen Bo, "Intellectual Journey," in Cornelis de Waal (ed.), Susan Haack: A Lady of Distinctions (Amherst, Prometheus Books, 2007), 17-37, p. 30-1.

178. See e.g., Tung-Tsu Ch'u, Law and Society in Traditional China (Paris, Mouton \& Co., 1961); Xia Yong, The Philosophy of Civil Rights in the Context of China (Leiden, the Netherlands, Martinus Nijhof, 2011) (both drawn to my attention by Li Xudong).

179. See note 106 above. 
180. I allude here to Catherine Drinker Bowen's fictionalized life of Holmes, The Yan kee from Olympus (Boston, Little, Brown, 1944); and to Yogat's description of what he finds disturbing about Holmes the man, "detachment." Rosal Yogat, "Mr. Justice Holmes: Some Modern Views," University of Chicago Law Review, 31.2, 1964: 21-36.

\section{AUTHOR}

\section{SUSAN HAACK}

University of Miami School of Law

shaack[at]law.miami.edu 